\title{
Comparison of biological activities of Tityus pachyurus venom from two Colombian regions
}

\author{
Jennifer Alexandra Solano-Godoy ${ }^{1}$, Julio César González-Gómez ${ }^{2,3,4}$, Kristian A. Torres-Bonilla ${ }^{5}$, \\ Rafael Stuani Floriano ${ }^{6}$ (D), Ananda T. Santa Fé Miguel ${ }^{5}$, Walter Murillo-Arango ${ }^{1 *}$ (i) \\ ${ }^{1}$ Natural Products Research Group (GIPRONUT), School of Sciences, University of Tolima, Altos de Santa Helena, Ibagué, Tolima, Colombia. \\ ${ }^{2}$ Research Group BEA - Biology and Ecology of Arthropods, Corporación Huiltur, Neiva, Huila, Colombia. \\ ${ }^{3}$ School of Sciences, University of Tolima, Altos de Santa Helena, Ibagué, Tolima, Colombia. \\ ${ }^{4}$ Research Group on Bio-ecology of Vertebrates (BIVET), Fundación Merenberg, La Plata, Huila, Colombia. \\ ${ }^{5}$ Department of Pharmacology, School of Medical Sciences, State University of Campinas (Unicamp), Campinas, SP, Brazil. \\ ${ }^{6}$ Laboratory of Toxinology and Cardiovascular Research (LATEC), Graduate Program in Health Sciences, University of Western São Paulo (Unoeste), \\ Presidente Prudente, SP, Brazil.
}

\section{Keywords:}

Scorpion

Venom

Insecticides

Antibacterial agents

Chromatography

HPLC

\begin{abstract}
Background: In the present study, we have tested whether specimens of the medically relevant scorpion Tityus pachyurus, collected from two climatically and ecologically different regions, differ in the biological activities of the venom.

Methods: Scorpions were collected in Tolima and Huila, Colombia. Chemical profiles of the crude venom were obtained from 80 scorpions for each region, using SDS-PAGE and RP-HPLC. Assays for phospholipase $\mathrm{A}_{2}$, direct and indirect hemolytic, proteolytic, neuromuscular, antibacterial, and insecticidal activities were carried out.

Results: The electrophoretic profiles of venom from the two regions showed similar bands of 6-14 kDa, 36-45 kDa, $65 \mathrm{kDa}$ and $97 \mathrm{kDa}$. However, bands between $36 \mathrm{kDa}$ and $65 \mathrm{kDa}$ were observed with more intensity in venoms from Tolima, and a $95 \mathrm{kDa}$ band occurred only in venoms from Huila. The chromatographic profile of the venoms showed differences in the intensity of some peaks, which could be associated with changes in the abundance of some components between both populations. Phospholipase $\mathrm{A}_{2}$ and hemolytic activities were not observable, whereas both venoms showed proteolytic activity towards casein. Insecticidal activity of the venoms from both regions showed significant variation in potency, the bactericidal activity was variable and low for both venoms. Moreover, no differences were observed in the neuromuscular activity assay. Conclusion: Our results reveal some variation in the activity of the venom between both populations, which could be explained by the ecological adaptations like differences in feeding, altitude and/or diverse predator exposure. However more in-depth studies are necessary to determine the drivers behind the differences in venom composition and activities.
\end{abstract}

\footnotetext{
* Correspondence: wmurillo@ut.edu.co
} https://doi.org/10.1590/1678-9199-JVATITD-2021-0005 Received: 19 January 2021; Accepted: 26 April 2021; Published online: 6 December 2021 


\section{Background}

Scorpion venoms represent a complex mixture of neurotoxins, enzymes, proteins and peptides secreted by a specific gland inside the telson [1]. The neurotoxins mostly affect ion channels, mainly potassium $\left(\mathrm{K}^{+}\right)$and sodium $\left(\mathrm{Na}^{+}\right)$channels of neurons, and have been shown to play an important role in the ecology of scorpions, as well as in pharmacology and agricultural industry [1]. Scorpions have evolved specific toxins that specially affect ion channels of vertebrates or arthropods. Scorpions can therefore use their venoms to capture different types of arthropod preys, and also defend themselves from vertebrate predators [2]. In addition, ion channel toxins selective for arthropods can serve as templates for the development of new pesticides as sustainable solutions for the agricultural industry [3-6]. Furthermore, some peptides from scorpion venoms have gained interest in the pharmaceutical industry for their antimicrobial activities, due to the presence of antimicrobial peptides (AMPs). These peptides have been extensively evaluated as therapeutic agents based on their potent activities, low resistance rates and unique mechanisms of action [7-9].

Venom components may be more abundant in some individuals of a species than others due to the individual variability in the composition of venom. The variation occurring between individual venom samples can be a result of seasonal variation, diet, habitat, predator exposure, age and/or gender [10-12].

Intraspecific variation of venoms has been previously studied in different species of venomous animals, such as bees [13], wasps [14], ants [15], Cone shell snails [16], spiders [17], snakes [11,18] and scorpions [10,19-21]. Abdel-Rahman et al. [10], reported intraspecific variation in the Egyptian scorpion Scorpio maurus palmatus (Scorpionidae), and attributed it to environmental conditions or a reflection of genetic diversity among populations. Similarly, Estrada-Gómez et al. [20], reported intraspecific differences in the venom composition of Centruroides edwardsii from two regions of Colombia, which were attributed to an innate individual variation in the synthesis and expression of the venom. It therefore appears that local environmental conditions and geographical separation could play an important role in intraspecific variation.

The intraspecific variation in venom composition may have an effect on the biological activities, the mechanisms of action of the venom and on the symptomatology presented by the patients and their responses to antivenoms. Differences in bioactivity of the venom may be a heuristic approach for the effective bioprospecting of its metabolites [18,22].

T. pachyurus is a species of medical importance in Colombia, and its venom is considered one of the most toxic, and responsible for the highest percentage of scorpion sting patient admissions to hospitals in the country [11,23-25]. Envenomation by this species can present symptoms such as tachycardia, diaphoresis, tachypnea, cyanosis, hypertension, and bradycardia. In cases of severe scorpionism, cardiovascular compromise and cardiac arrest, and pulseless ventricular tachycardia are also present [26].
In this work, we compared the venom of Tityus pachyurus collected in two different departments in Colombia (Huila and Tolima), finding some differences in toxicity, enzymatic and biological activities of the venoms. This study represents a further advance towards the comprehension of the variability of venom composition of the medically important scorpion T. pachyurus.

\section{Methods}

\section{Animal collection and housing}

\section{Scorpions}

Eighty (80) adult scorpions per region were manually collected between the following hours: 20:00 and 00:00. We did not differentiate between males and females. All individuals collected were adults. Specimen collection was carried out under the permit granted by ANLA, resolution 00319 of March 29, 2017.

Scorpions were collected using ultraviolet lamps in different locations in diverse altitudes (Fig. 1):

- Ibagué, Tolima (1100 m ASL): Alexander Von Humboldt Botanical Garden $\left(4^{\circ} 25^{\prime} 36.60^{\prime \prime}\right.$ N, $75^{\circ} 12^{\prime} 48.47^{\prime \prime}$ W) and San Jorge Botanical Garden ( $4^{\circ} 26^{\prime} 52.50^{\prime \prime}$ N, 75 $13^{\prime} 34.10^{\prime \prime} \mathrm{W}$ ).

- Rivera, Huila (920 m ASL): surroundings of Los Ángeles Termal $\left(2^{\circ} 45^{\prime} 7.5^{\prime \prime} \mathrm{N}, 75^{\circ} 14^{\prime} 15.4^{\prime \prime} \mathrm{W}\right)$ and Granja Integral Modelo Experimental $\left(2^{\circ} 45^{\prime} 43.43 \mathrm{~N}, 75^{\circ} 15^{\prime} 17.33^{\circ} \mathrm{W}\right)$.

After collecting the scorpions, they were transported to the Laboratory of the Natural Products Research Group (GIPRONUT, Universidad del Tolima). Each scorpion was kept individually in a plastic box with dry soil and a wet cotton to provide water. After experiments all the individuals were deposited in the Zoology Collection of the University of Tolima (CZUTARA-16D282DC7BD).

\section{Experimental animals}

Male Balb/c mice (25-30 g, 2-3 months old) obtained from the Multidisciplinary Center for Biological Investigation of the State University of Campinas (CEMIB/UNICAMP, Campinas, SP, Brazil) were housed in plastic cages (5-10/cage) with a woodshaving substrate, at $23 \pm 1{ }^{\circ} \mathrm{C}$ in ventilated stands (Alesco') on a $12 \mathrm{~h}$ light/dark cycle with lights on at 6 a.m. Animals had free access to food and water. The animals were euthanized with isoflurane (saturated atmosphere) immediately prior to the experiments. The animal experiments were approved by an institutional Committee for Ethics in Animal Use of the State University of Campinas (CEUA/UNICAMP, protocol no. 50931/2018) and were done according to the general ethical guidelines for animal use established by the Brazilian Society of Laboratory Animal Science (SBCAL) and Brazilian legislation (Federal Law No. 11,794, of October 8, 2008), in conjunction with the guidelines for animal experiments established by the Brazilian National Council for Animal Experimentation (CONCEA) and EU Directive 2010/63/EU for the Protection of Animals Used for Scientific Purposes. 


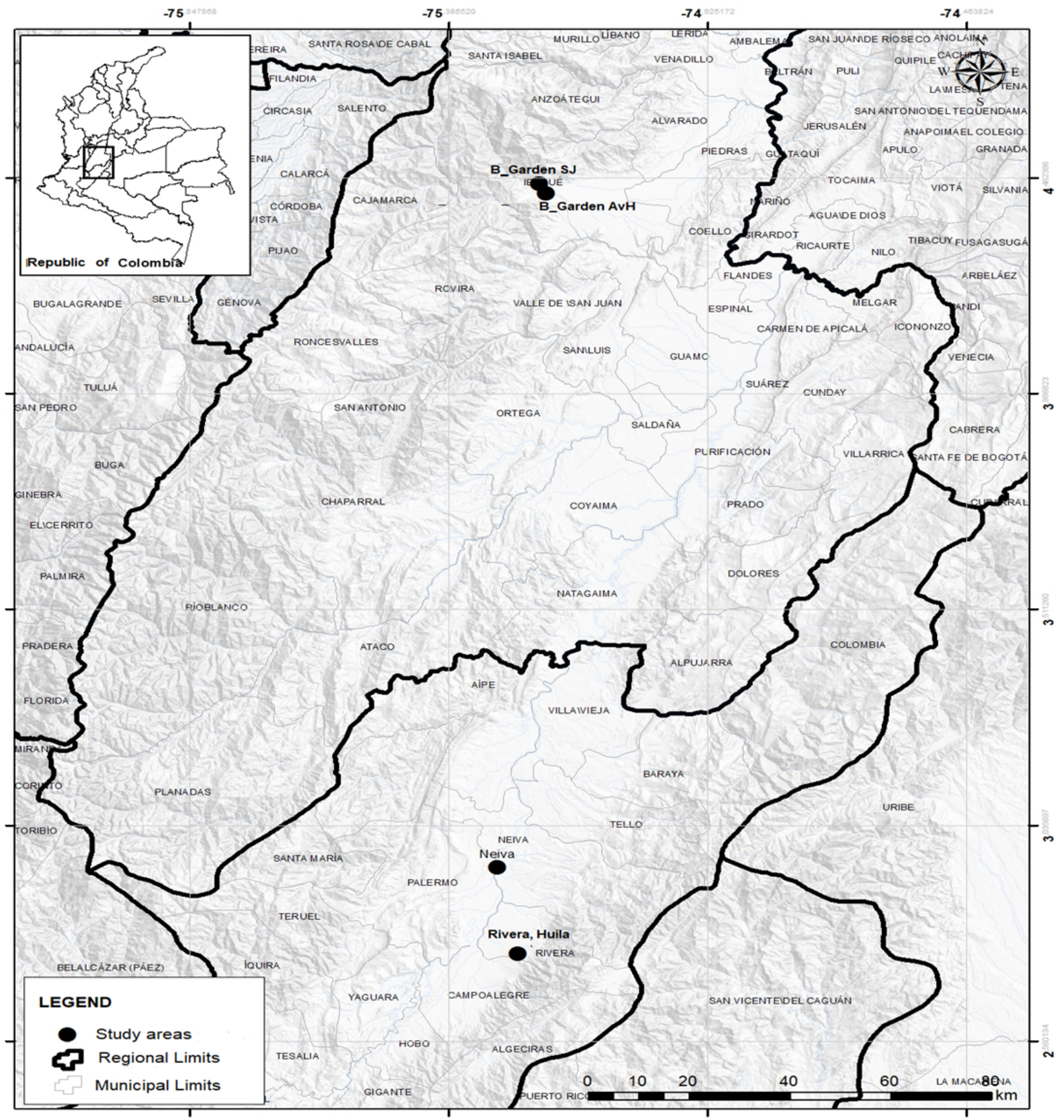

Figure 1. Location of sampling regions from Tolima and Huila departments in Colombia.

Cockroaches Blaptica dubia were used as a biological model in their third instar and kept in $12 \mathrm{Oz}$ jars with food and a wet cotton to ensure humidity and water availability

\section{Venom extraction}

Venom from T. pachyurus adult specimens was extracted by electrical stimulation on the metasoma through a power source $(18 \mathrm{~V}, 40 \mathrm{~Hz})[12,27]$. The collected venom was pooled per region, transferred to low-protein binding tubes, lyophilized and stored at $-20^{\circ} \mathrm{C}$ until their use.

\section{Venom characterization}

The protein content quantification was determined in triplicate using standard curves of bovine serum albumin (BSA) between 0 and $125 \mathrm{mg} / \mathrm{mL}$ solutions, with absorbance being measured at $595 \mathrm{~nm}$, as essentially described elsewhere [28].

\section{Sodium dodecyl sulphate-polyacrylamide gel electrophoresis (SDS-PAGE)}

The samples were separated in gels at $12 \%(\mathrm{v} / \mathrm{v})$ following the protocol suggested by Yábar et al. [29], loading $8.53 \mu$ g protein 
per sample. Gels were run at a constant voltage of $100 \mathrm{~V}$ for 60 minutes, and were then stained with Coomassie Brilliant Blue R-250. The molecular mass was estimated with two SigmaAldrich (St. Louis, MO, USA) standard markers: C1992-1VL and S8445-1VL.

\section{Reverse-phase high performance liquid chromatography (RP-HPLC)}

Reverse-phase HPLC (RP-HPLC) of T. pachyurus venom from Tolima and Huila region was carried out using a Discovery C18 column (250 mm x 4.6 mm x $5 \mu \mathrm{m} ; 300 \AA$ ) from SigmaAldrich Chemical Co. (St. Louis, MO, USA) coupled to a Shimadzu chromatographic system (Shimadzu, Tokyo, Japan) that consisted of two pumps (LC10AD VP), a UV/Vis detector (SPD-10A), a fraction collector (FRC-10A) and a system controller (SCL-10A VP). The column was initially equilibrated with $0.1 \%(\mathrm{v} / \mathrm{v})$ trifluoroacetic acid (TFA). The venom $(1 \mathrm{mg})$ was dissolved in ultrapure water with $0.1 \%(\mathrm{v} / \mathrm{v})$ TFA and clarified by centrifugation ( $112 \mathrm{xg}$ for $5 \mathrm{~min}$ ). Proteins were eluted with a linear gradient (0-100\%) of $99.9 \%$ acetonitrile in $0.1 \%$ TFA and the elution profile was monitored at 280 and $215 \mathrm{~nm}$ [30-32].

\section{Enzymatic activities}

\section{Phospholipase $A_{2}$ and hemolytic activity}

The venom samples were tested at different concentrations $(0.25-$ $10 \mu \mathrm{g} / \mu \mathrm{L}$ ) with a lipoprotein solution from egg yolk in the presence of $\mathrm{CaCl}_{2}$. The hydrolysis of the phospholipids was detected after 15 minutes of incubation at $37^{\circ} \mathrm{C}$. It was standardized with 0.01 mol xl $l^{-1}$ sodium hydroxide $(\mathrm{NaOH})$, and the results was expressed in $\mu \mathrm{mol}$ of fatty acid/mg of venom/minute [33].

Direct and indirect hemolytic activity was evaluated using agarose gels with red blood cells, in the presence or absence of calcium chloride $\left(\mathrm{CaCl}_{2}\right)$ with egg yolk solution. Minimum hemolytic dose (MHD) was defined as the amount of venom that induced a $20 \mathrm{~mm}$ diameter hemolytic halo. As a positive control Crotalus durissus venom was used at a concentration of $2 \mu \mathrm{g} / \mu \mathrm{L}$, and $0.25 \mathrm{M}$ phosphate buffer $\mathrm{pH} 7.0$ was used as a negative control [34].

\section{Proteolytic activity}

Casein (C7078; Sigma-Aldrich Chemical Co., St. Louis, MO, USA) was used as substrate to measure the proteolytic activity of all venoms, using the methodology reported by Kunitz [35] with modifications as follows: $250 \mu \mathrm{L}$ of venom at different concentrations $(0.5-4 \mu \mathrm{g} / \mu \mathrm{L})$ selected according to preliminary analyses (data not shown) were added with $750 \mu \mathrm{L}$ of casein at a concentration of $1 \%(\mathrm{v} / \mathrm{v})$, the mixture was incubated for 15 min at $37^{\circ} \mathrm{C}$, after which the reaction was stopped with $30 \%$ (v/v) trichloroacetic acid (TCA) [36-38].

Samples were then centrifuged at $2800 \mathrm{x}$ g for $10 \mathrm{~min}$ at $25{ }^{\circ} \mathrm{C}$. The resulting proteolytic products were evaluated spectrophotometrically at $\chi=280 \mathrm{~nm}$. Results are shown as units of caseinolytic activity using the following formula: $\mathrm{U} / \mathrm{mg}$
$=\left(\Delta \mathrm{A} 280 / \mathrm{mg}_{\text {venom }}\right) \mathrm{x}(100)$ which correspond to the amount that induces a change in absorbance of $0.001 /$ minute. Each test was performed in triplicate and all reagents were analytical grade.

\section{Biological activities}

\section{Bactericidal activity}

The bactericidal activity was assayed in 96-well microplates, in which $130 \mu \mathrm{L}$ of the bacterial culture was placed in Brain Heart Infusion (BHI) with an initial absorbance at $610 \mathrm{~nm}$ in a Multiskan $^{\mathrm{TM}}$ Go microplate spectrophotometer and $70 \mu \mathrm{L}$ of the respective venom. After 24 hours at $37^{\circ} \mathrm{C}$, bacterial growth was determined by the turbidity developed in each well. The inhibitory effect was determined by the absence of turbidity [39-41].

Bacterial strains obtained from the pathogenic strains collection of the Natural Products Research Group (GIPRONUT) of the University of Tolima were tested separately: Escherichia coli (ATCC25922), Pseudomonas aeruginosa (ATCC27853) and Staphylococcus aureus (ATCC29213).

\section{Insecticidal activity}

Insecticidal activity for T. pachyurus venoms was determined in cockroaches Blaptica dubia, as essentially described elsewhere [42-44]. Cockroaches (12/batch) were grouped according to similar mass ranges between $90 \mathrm{mg}$ to $250 \mathrm{mg}$. Three replicates were performed for a total of 36 individuals per dose, with a venom exposure of $48 \mathrm{~h}$. The venom was diluted to be administrated with $0.25 \mathrm{M}$ phosphate buffer at $\mathrm{pH} 7.0$ and tested with two doses $(30$ and $100 \mu \mathrm{g})$ through injection in the third segment of the ventral abdomen of each individual. As a positive control, cockroaches were treated with doses of $60 \mu \mathrm{g}$ Malathion $57 \%$ EC ADAMA (commercial insecticide). As a negative control, cockroaches were treated with $0.25 \mathrm{M}$ phosphate buffer at $\mathrm{pH}$ 7.0. Individuals were considered dead when they did not respond to any stimulus applied to the appendages with a brush, and mortality was recorded 24 hours and 48 hours after treatment. The batches were observed at 1 hour, 10 hours, 24 hours and 48 hours after envenomation. The median lethal time $\left(\mathrm{LT}_{50}\right)$ and the median lethal dose $\left(\mathrm{LD}_{50}\right)$ was estimated by Probit analysis.

\section{Mouse phrenic nerve-diaphragm (PND) preparations}

The hemidiaphragms and their respective phrenic nerves were dissected from male Swiss mice euthanized with isoflurane (saturated atmosphere) and then the preparations were mounted under a resting tension of $1 \mathrm{~g}$ in $5 \mathrm{~mL}$ organ baths containing aerated $\left(95 \% \mathrm{O}_{2}\right.$ and $\left.5 \% \mathrm{CO}_{2}\right)$ Tyrode solution (composition, in mM: $\mathrm{NaCl} 137, \mathrm{KCl} 2.7, \mathrm{CaCl}_{2} 1.8, \mathrm{MgCl}_{2} 0.49, \mathrm{NaH}_{2} \mathrm{PO}_{4} 0.42$, $\mathrm{NaHCO}_{3} 11.9$ and glucose 11.1, pH 7.0) at $37^{\circ} \mathrm{C}$ and allowed to stabilize for $10 \mathrm{~min}$ prior to use, as described elsewhere [45]. Supramaximal stimuli $(0.1 \mathrm{~Hz}, 0.2 \mathrm{~ms})$ were delivered to the nerve from a Grass S88 stimulator (Grass Instrument Co., Quincy, MA, USA) and the muscle twitches were recorded using a TRI201AD force displacement transducer coupled to a Quad Bridge Amp and LabChart 6.0 software (all from ADInstruments Pty Ltd., 
Bella Vista, Australia). After stabilization, the preparations were incubated with T. pachyurus venom (10,30 and $60 \mu \mathrm{g} / \mathrm{mL})$ for 120 min or until complete neuromuscular blockade. Changes in the twitch-tension responses of PND preparations were expressed as a percentage relative to baseline (time zero) values.

\section{Neutralizing effect of scorpion antivenom from Brazil}

The neutralizing action of scorpion antivenom produced by the Instituto Butantan (São Paulo, SP, Brazil) on the T. pachyurus venom-induced neuromuscular blockade in mouse PND preparation was tested by incubating venom at an antivenom:venom ratio of 1:1 (v/w). This ratio was based on the manufacturers stated neutralizing capacity for the antivenom in which $1 \mathrm{~mL}$ of antivenom neutralizes $1 \mathrm{mg}$ of Tityus serrulatus venom. T. pachyurus venom from Huila and Tolima regions was pre-incubated with antivenom at $37^{\circ} \mathrm{C}$ for $30 \mathrm{~min}$ before assaying for residual neuromuscular activity in PND preparation [45].

\section{Statistical analyses}

The results were expressed as the mean \pm SDM. Statistical comparisons were made using a two-way ANOVA followed by the Tukey post-hoc test, with $p<0.05$ indicating significance. The original data met the criteria of normal curve fit and homogeneity of variances.

\section{Results}

\section{Characterization of venom: SDS-PAGE electrophoresis and chromatographic profile}

The electrophoretic profiles showed differences between scorpion venom from Huila and Tolima (Fig. 2). Bands close to $65 \mathrm{kDa}$ were found only for Huila and bands close to $84 \mathrm{kDa}$ and 97 $\mathrm{kDa}$ were found in less intensity for Tolima compared with Huila, bands close 55-36 kDa were found in less intensity for Huila compared with Tolima (Table 1). The RP-HPLC venom

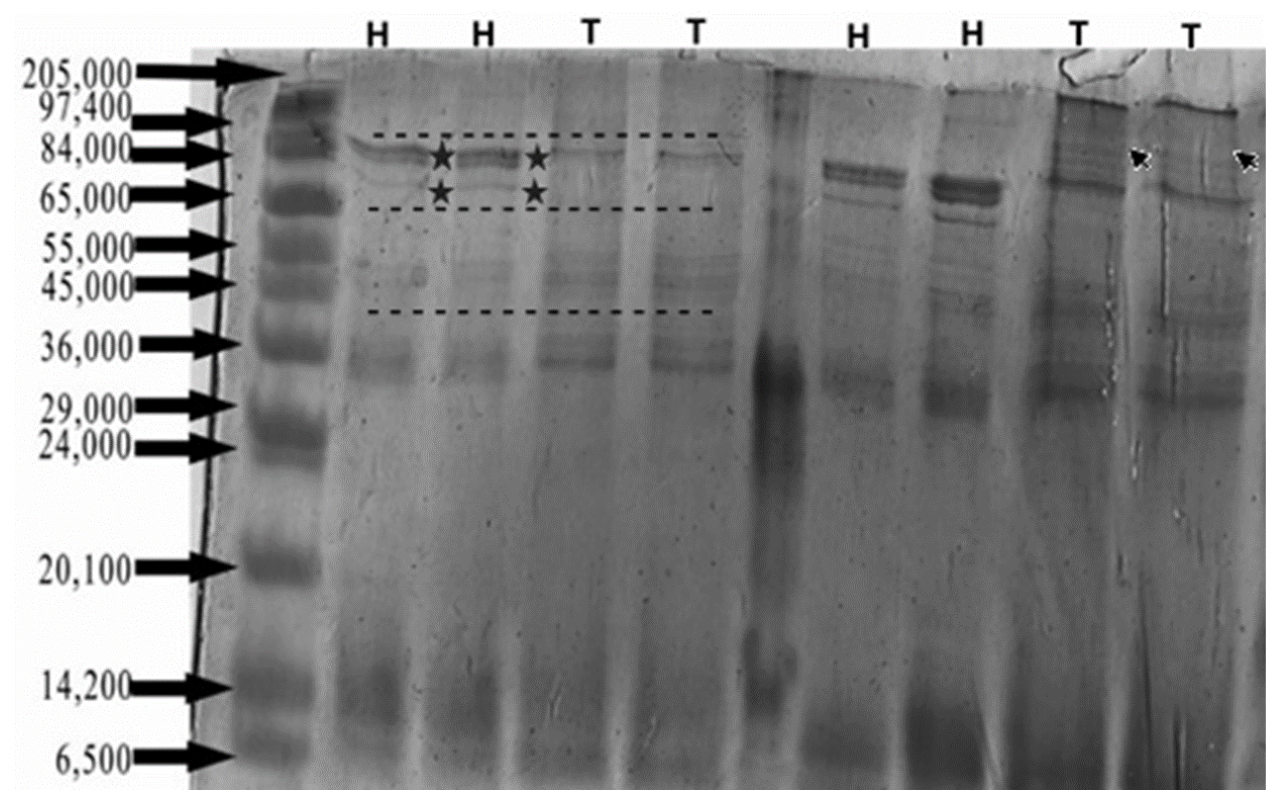

Figure 2. SDS-PAGE (12\%) profile of venoms from Huila $(H)$ and Tolima $(T)$ regions. Stars indicate protein bands present in T. pachyurus venom from the Huila region and absent in T. pachyurus venom from Tolima. Arrows indicate protein bands present in T. pachyurus venom from Tolima and absent in venom from the Huila region.

Table 1. SDS-PAGE (12\%) profile of scorpion venoms from Huila $(H)$ and Tolima $(T)$ regions. One plus $(+)$ symbol indicates the band presence, two symbols (++) indicate more abundance of a band and a negative one $(-)$ indicates the band absence.

\begin{tabular}{lccc}
\hline \multirow{2}{*}{ Protein band (kDa) } & \multicolumn{3}{c}{ Venom sample origin } \\
\cline { 2 - 4 } & Huila & $(+)$ & $(+)$ \\
\hline 97.4 & $(++)$ & $(-)$ & $(++)$ \\
84 & $(++)$ & $(+)$ & $(++)$ \\
65 & $(+)$ & $(++)$ & $(+)$ \\
55 & $(+)$ & $(+)$ & $(+)$ \\
14.2 & $(+)$ & $(+)$ & $(-)$ \\
6.5 & & & $(+)$ \\
\hline
\end{tabular}


profile showed approximately 50 to 55 peaks and the major components were in a well conserved region in both venoms eluting in the range of 25.43 to 43.63 min elution time between $17 \%$ to $50 \%$ of ACN (Fig. 3).
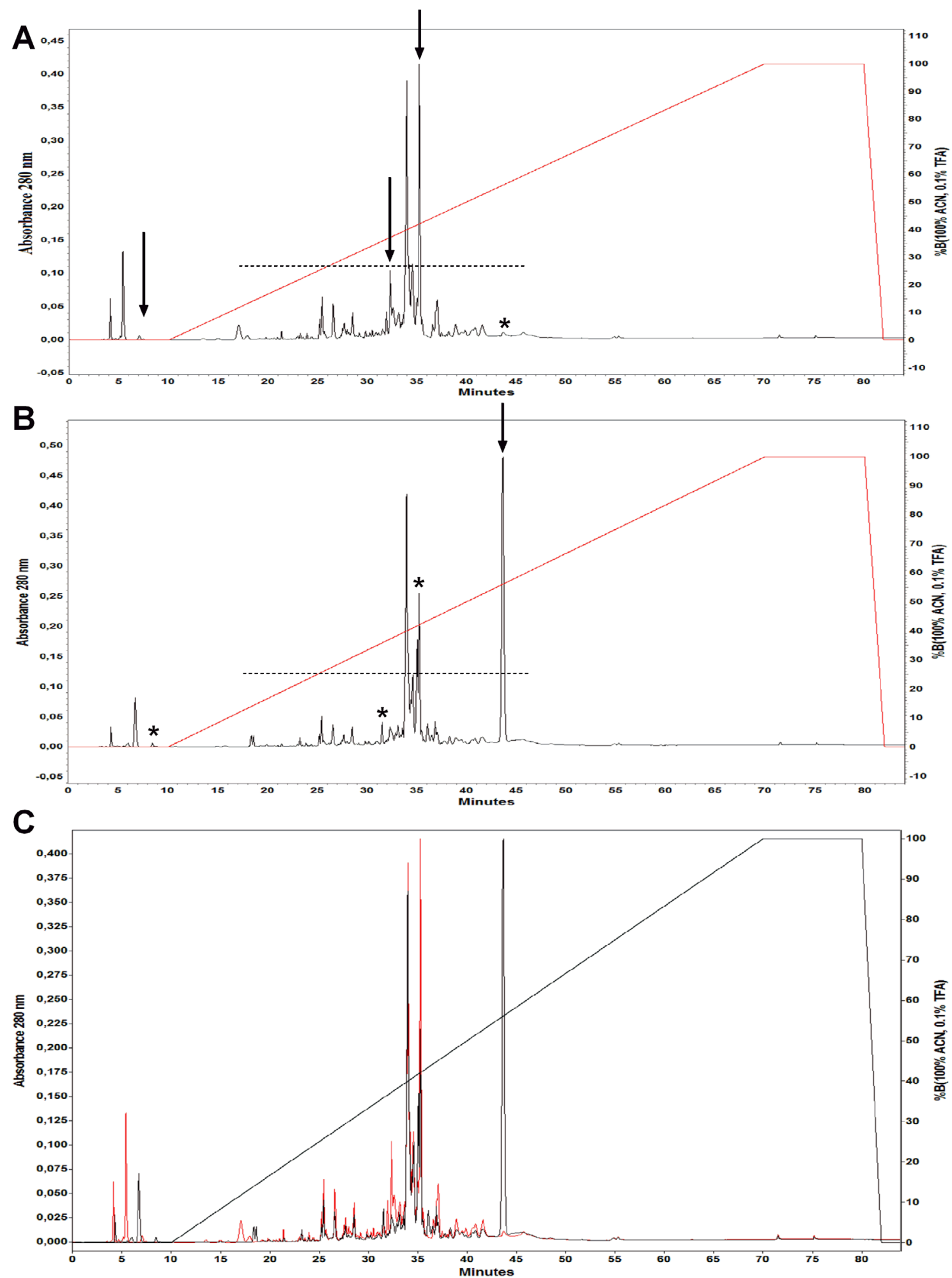

Figure 3. Separation by high performance liquid chromatography (RP-HPLC) of $1.0 \mathrm{mg}$ of soluble venom of Tityus pachyurus from (A) Tolima and (B) Huila regions. The profile was performed on an inverted Discovery C18 analytical column equilibrated with solution A (water in $0.1 \%$ TFA) (v/v), the proteins were eluted with a linear gradient $(0-100 \%)$ of $99.9 \%$ acetonitrile in $0.1 \%(v / v)$ TFA and the elution profile was monitored at $280 \mathrm{~nm}$. Arrows indicate the presence of peaks with higher intensity; asterisks indicate the absence of peaks, or peaks with less intensity; and dotted lines indicate a conserved region in both venoms. (C) Overlap of the chromatographic profiles of T. pachyurus venom from Tolima (red line) and Huila (black line). 


\section{Enzymatic activities}

T. pachyurus venom did not show phospholipase $\mathrm{A}_{2}$ activity on egg yolk substrate nor indirect or direct hemolytic activity for either of the two regions. The venom from both regions showed proteolytic activity on casein substrate at doses higher than 1 $\mathrm{mg} / \mathrm{mL}$. The caseinolytic activity differed significantly $(p<0.01)$ between Huila and Tolima at $4 \mathrm{mg} / \mathrm{mL}$ (Fig. 4).

\section{Biological activities}

\section{Bactericidal activity}

The inhibition percentages were variable and less than $50 \%$ for the two venoms and a dose response effect was not evident. The Tolima venom showed a percentage of inhibition of bacterial growth of $36 \%$ against the gram-positive bacterium $S$. aureus while the venom from Huila showed inhibition of bacterial growth of $26 \%$ against the gram-negative bacterium $E$. coli. The two remaining strains did not show any type of inhibition. The data are shown in Table 2.

\section{Insecticidal activity}

We observed a difference in the toxicity between the venoms from Huila and Tolima. Venom from Huila presented insecticidal activity in Blaptica dubia. The cockroaches exposed to the treatment with the Tolima venom showed fewer envenomation symptoms, lower toxicity, and did not produce a significant mortality in the individuals exposed. It was not possible to calculate the $\mathrm{LD}_{50}$ for the Tolima venom, since none of the individuals died with the injected doses. On the other hand, the individuals exposed to venom from Huila showed a faster envenomation $\left(\mathrm{LT}_{50}\right.$ of $\left.52 \mathrm{~min}\right)$ and higher mortality $\left(\mathrm{LD}_{50}\right.$ of $843.8 \mathrm{mg} / \mathrm{kg})$.

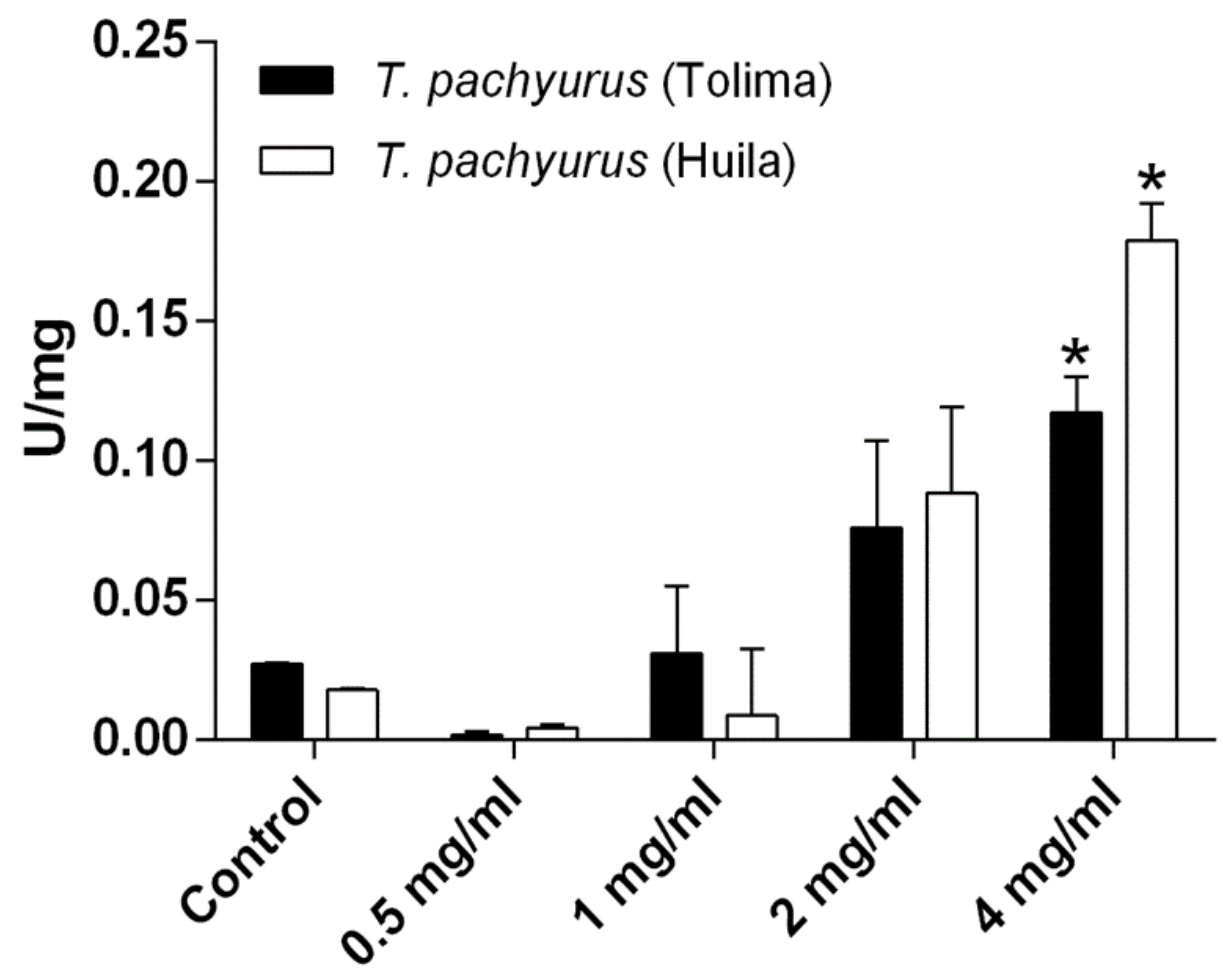

Figure 4. Proteolytic activity towards casein of venom from Tityus pachyurus from Tolima and Huila regions. ${ }^{*} p<0.05$ two-way ANOVA compared to each other.

Table 2. Percentage of bactericidal inhibition caused by T. pachyurus venom from Tolima and Huila regions.

\begin{tabular}{lcccccc}
\hline Bacterial strain & Sample & $\mathbf{3 1} \mathbf{~ p p m}$ & $\mathbf{6 2} \mathbf{~ P p m}$ & $\mathbf{1 2 5} \mathbf{~ P p m}$ & $\mathbf{2 5 0} \mathbf{~ p p m}$ & $\mathbf{5 0 0} \mathbf{p p m}$ \\
\hline \multirow{2}{*}{ Staphylococcus aureus } & Tolima & $36.5 \pm 15.48$ & $43.4 \pm 9.32$ & $48.6 \pm 5.89$ & $21.2 \pm 25.7$ & $46.3 \pm 5.46$ \\
& Huila & 0 & $0.03 \pm 2.53$ & 0 & 0 & 0 \\
Pseudomona aeuroginosa & Tolima & $0.05 \pm 0.05$ & $0.05 \pm 0.06$ & $0.06 \pm 0.03$ & $0.06 \pm 0.02$ & $0.05 \pm 0.08$ \\
& Huila & $5.07 \pm 2.69$ & $12.71 \pm 7.09$ & 0 & 0 & 0 \\
Escherichia coli & Tolima & $0.32 \pm 0.06$ & $0.27 \pm 0.06$ & $0.19 \pm 0.03$ & $0.15 \pm 0.06$ & $0.15 \pm 0.04$ \\
& Huila & $26.17 \pm 4.72$ & $25.73 \pm 1.38$ & $22.55 \pm 4.03$ & $19.42 \pm 8.571$ & $21.32 \pm 26.27$ \\
\hline
\end{tabular}

Data are reported as the mean \pm SDM. 
The first symptoms of envenomation were evident one hour after treatment in the batches injected with Huila venom: uncoordinated displacement and rapid movements. After ten hours the cockroaches that remained alive responded to the stimulation of their appendices, but they did not have the capacity to displace; finally, after 24 hours there were signs of mortality.

\section{Neuromuscular activity and neutralization}

T. pachyurus venom $(10 \mu \mathrm{g} / \mathrm{mL})$ from Tolima caused progressive neuromuscular facilitation which reached $48 \pm 12 \%$ of increasing in twitch amplitude after $120 \mathrm{~min}$ incubation $(p<0.05$ compared to control preparations, $n=4)$; venom produced concentrationdependent neuromuscular blockade with the intermediary concentration $(30 \mu \mathrm{g} / \mathrm{mL})$ decreasing $30 \pm 17 \%$ of twitch responses after $120 \mathrm{~min}$ incubation and the highest concentration $(60 \mu \mathrm{g} / \mathrm{mL})$ causing complete blockade in $\sim 40 \mathrm{~min}$ incubation (times for $50 \%$ and $90 \%$ blockade: $\sim 10$ and $\sim 38 \mathrm{~min}$, respectively; $p<0.05$ compared to control preparations, $\mathrm{n}=4$ ); there was no evidence for neuromuscular facilitation with the 30 and $60 \mu \mathrm{g} /$ $\mathrm{mL}$ venom concentrations (Fig. 5A, Table 3). The neuromuscular blockade induced by T. pachyurus venom from Tolima (60 $\mu \mathrm{g} /$ $\mathrm{mL}$ ) was not neutralized by scorpion antivenom (Fig. 5B).
In summary, Figure $5 \mathrm{C}$ shows the endpoints recorded after 120 min incubation with Tyrode solution (control), venom (10-60 $\mu \mathrm{g} / \mathrm{mL}$ ) and venom pre-incubated with antivenom. Figure $5 \mathrm{D}_{1}$ shows the representative recording of the T. pachyurus venom from Tolima $(10 \mu \mathrm{g} / \mathrm{mL})$-induced neuromuscular facilitation whereas the Figure $5 \mathrm{D}_{2}$ is a representative recording of the $T$. pachyurus venom from Tolima $(60 \mu \mathrm{g} / \mathrm{mL})$-induced complete neuromuscular blockade in PND preparation.

T. pachyurus venom $(10 \mu \mathrm{g} / \mathrm{mL})$ from Huila also produced facilitatory responses reaching $56 \pm 14 \%$ of increase in twitch amplitude after $120 \mathrm{~min}$ incubation $(p<0.05$ compared to control preparations, $n=4$ ). In PND preparations exposed to 30 and $60 \mu \mathrm{g}$ of venom $/ \mathrm{mL}$, there was a concentration-dependent neuromuscular blockade with the intermediary concentration inducing partial blockade of the twitch responses ( $40 \pm 20 \%$ of blockade after 120 min incubation, $n=4$ ), whereas the highest concentration caused complete blockade after approximately 100 min incubation (times for 50\% and 90\% blockade: approximately 18 and $90 \mathrm{~min}$, respectively; $p<0.05$ compared to control preparations, $\mathrm{n}=4)$; $T$. pachyurus venom (30 and $60 \mu \mathrm{g} / \mathrm{mL}$ ) from Huila also did not produce neuromuscular facilitation prior to blockade (Fig. 6A, Table 2).
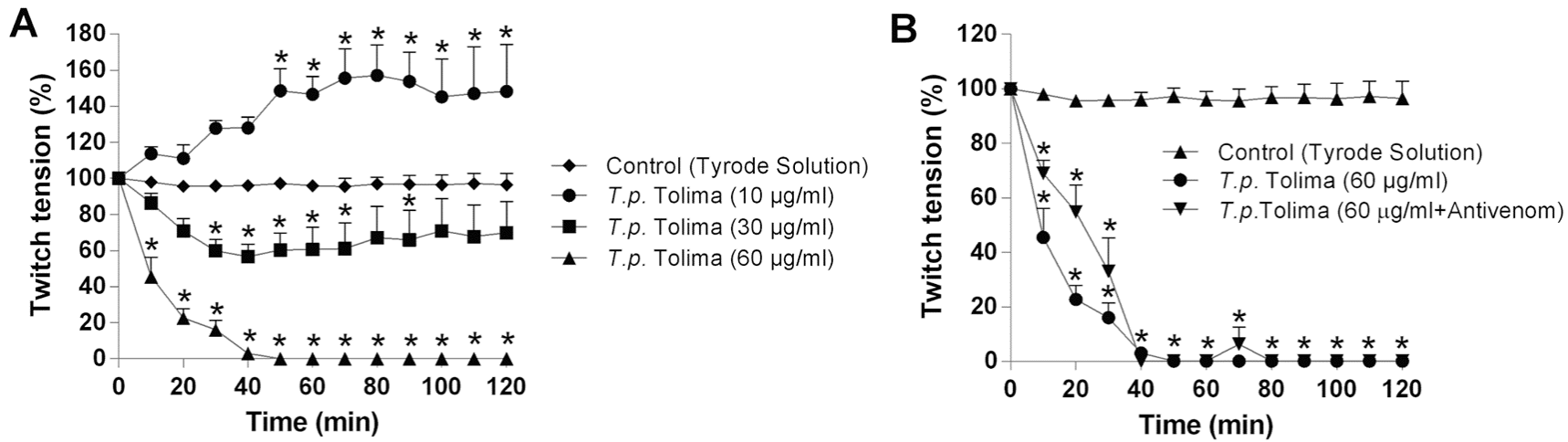

C

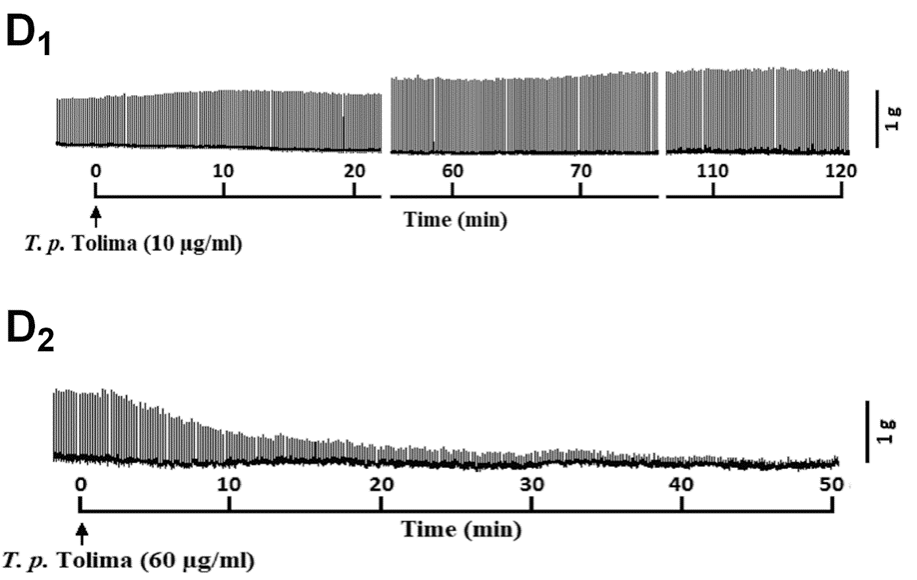

Figure 5. Neuromuscular activity of T. pachyurus venom from Tolima in PND preparations. (A) Neuromuscular effects induced by the venom at different concentrations. It was observed complete blockade with the highest concentration and facilitation with the lowest concentration after 120 min of incubation. (B) Failure of the scorpion antivenom from Brazil to inhibit the complete blockade induced by the venom. (C) Final twitch tension after 120 min of incubation with all the concentrations and antivenom. Representative recordings showing the facilitation induced by $\left(\mathbf{D}_{1}\right)$ the lowest concentration of venom and $\left(\mathbf{D}_{2}\right)$ the complete blockade produced by the highest concentration of venom. The points in $\mathbf{A}$ and $\mathbf{B}$ and columns in $\mathbf{C}$ are the mean \pm SEM $(n=4)$. *p $<0.05$ two-way ANOVA compared to control preparations. 
Table 3. Comparison of the potency of Tityus pachyurus and other Tityus venoms determined as the time required to induce neuromuscular blockade in mice phrenic nerve-diaphragm (PND) preparations. The $t_{50}$ and $t_{90}$ values were estimated from graphs provided in the cited publications.

\begin{tabular}{|c|c|c|c|c|c|}
\hline Scorpion specie & $\begin{array}{c}\text { Venom } \\
\text { concentration } \\
(\mu \mathrm{g} / \mathrm{mL})\end{array}$ & $\mathbf{T}_{50}(\mathrm{~min})$ & $\mathbf{T}_{90}(\mathrm{~min})$ & $\begin{array}{c}\text { Facilitation } \\
\text { (\%) }\end{array}$ & Reference \\
\hline \multirow[t]{2}{*}{ Tityus pachyurus (Huila-Colombia) } & 30 & NA & NA & NA & \multirow[t]{2}{*}{ This work } \\
\hline & 60 & $\sim 18$ & $\sim 90$ & NA & \\
\hline Tityus pachyurus (Tolima-Colombia) & 60 & $\sim 10$ & $\sim 38$ & NA & This work \\
\hline \multirow{3}{*}{ Tityus bahiensis (Brazil) } & 1 & NA & NA & $\sim 75$ & \multirow{3}{*}{ Collaço et al. [71] } \\
\hline & 3 & NA & NA & $\sim 30$ & \\
\hline & 10 & NA & NA & $\sim 50$ & \\
\hline
\end{tabular}

NA: not applicable (the venom concentration did not induce 50 or $90 \%$ neuromuscular blockade during the frame of the experiment).
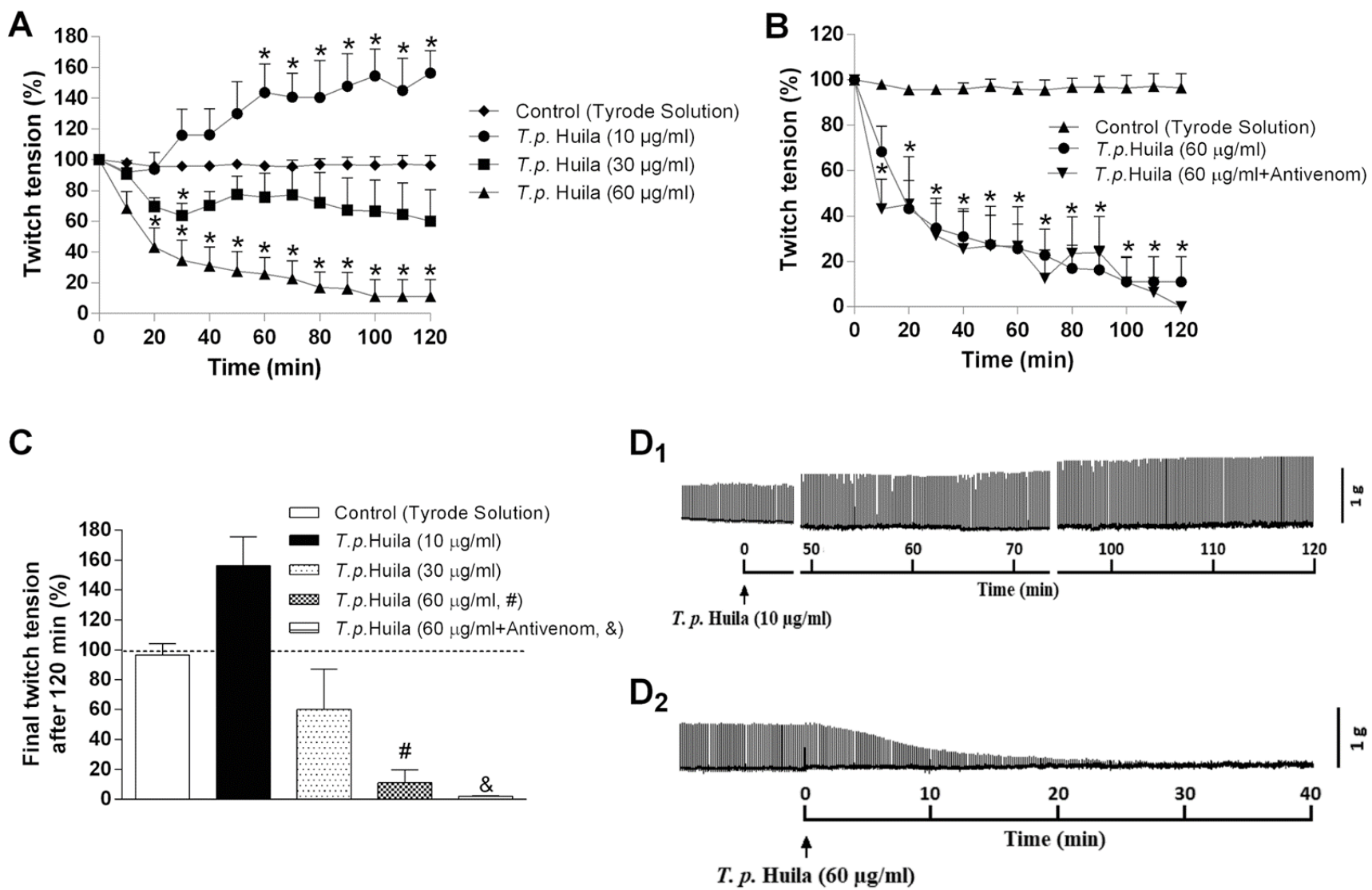

Figure 6. Neuromuscular activity of T. pachyurus venom from Huila in PND preparations. (A) Neuromuscular effects induced by the venom at different concentrations. It was observed complete blockade with the highest concentration and facilitation with the lowest concentration after 120 min of incubation. (B) Failure of the scorpion antivenom from Brazil to inhibit the complete blockade induced by the venom. (C) Final twitch tension after 120 min of incubation with all the concentrations and antivenom. Representative recordings showing the facilitation induced by $\left(\mathbf{D}_{1}\right)$ the lowest concentration of venom and $\left(\mathbf{D}_{2}\right)$ the complete blockade produced by the highest concentration of venom. The points in $\mathbf{A}$ and $\mathbf{B}$ and columns in $\mathbf{C}$ are the mean \pm SEM ( $=4$ ). $* p<0.05$ two-way ANOVA compared to control preparations. 
The neuromuscular blockade induced by T. pachyurus venom from Tolima $(60 \mu \mathrm{g} / \mathrm{mL})$ was not neutralized by scorpion antivenom (Fig. 6B). In summary, Figure 6C shows the endpoints recorded after 120 min incubation with Tyrode solution (control), venom $(10-60 \mu \mathrm{g} / \mathrm{mL})$ and venom pre-incubated with antivenom. Figure $6 \mathrm{D}_{1}$ shows the representative recording of the T. pachyurus venom from Huila $(10 \mu \mathrm{g} / \mathrm{mL})$-induced neuromuscular facilitation, whereas Figure $6 \mathrm{D}_{2}$ is a representative recording of the T. pachyurus venom from Huila $(60 \mu \mathrm{g} / \mathrm{mL})$ induced complete neuromuscular blockade in PND preparation.

T. pachyurus venoms from Huila and Tolima produced similar effects in PND preparations characterized by a progressive neuromuscular facilitation $(\sim 48-56 \%$ of increase in twitch amplitude) seen with the lowest concentration $(10 \mu \mathrm{g} / \mathrm{mL})$, whereas the intermediary concentration $(30 \mu \mathrm{g} / \mathrm{mL})$ caused partial neuromuscular blockade $(230 \%$ of reduction in twitch amplitude) after 120 min incubation. The highest concentration $(60 \mu \mathrm{g} / \mathrm{mL})$ produced complete neuromuscular blockade within 40-90 min (Fig. 7). The complete neuromuscular blockade seen with by both of these venoms was not affected by pre-incubation with scorpion antivenom.

Histological analysis of the preparations treated with Tityus pachyurus venom from Huila and Tolima did not reveal any morphological alteration, with no morphological difference compared to those control preparations incubated with Tyrode solution (data not shown).

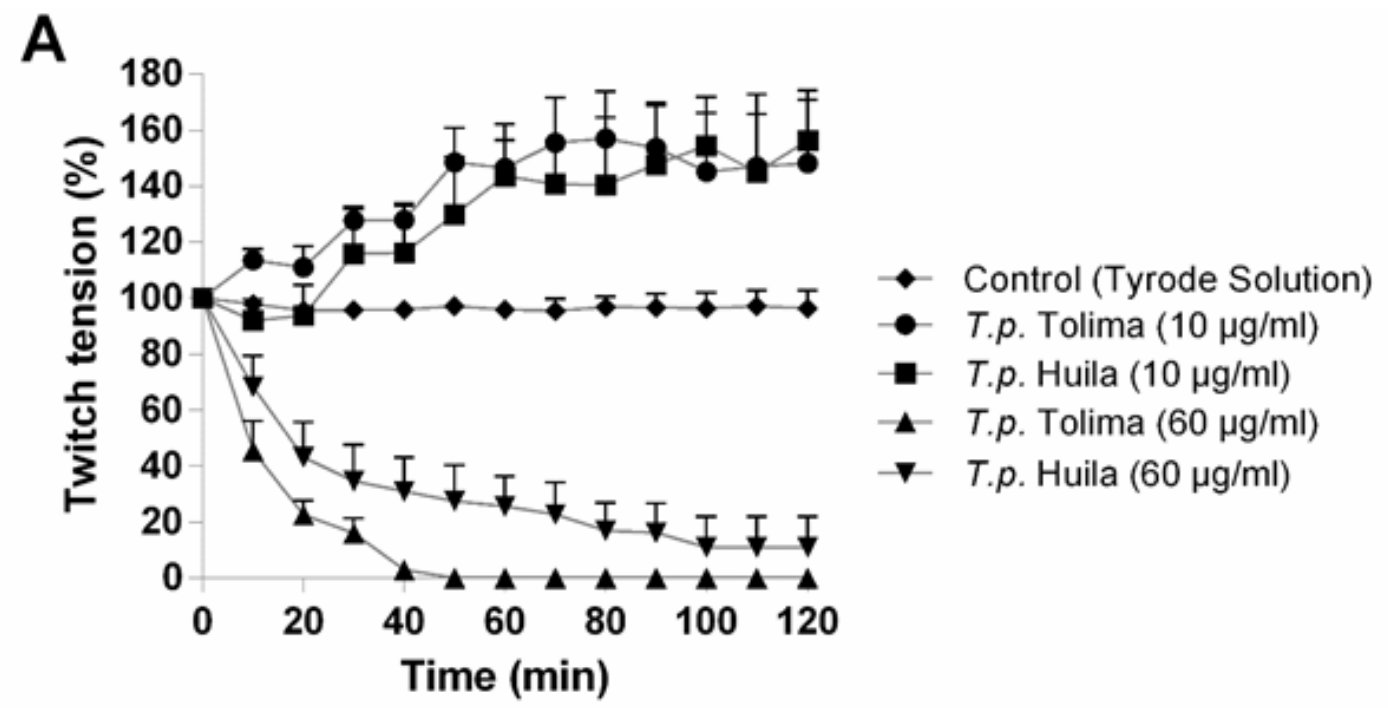

B

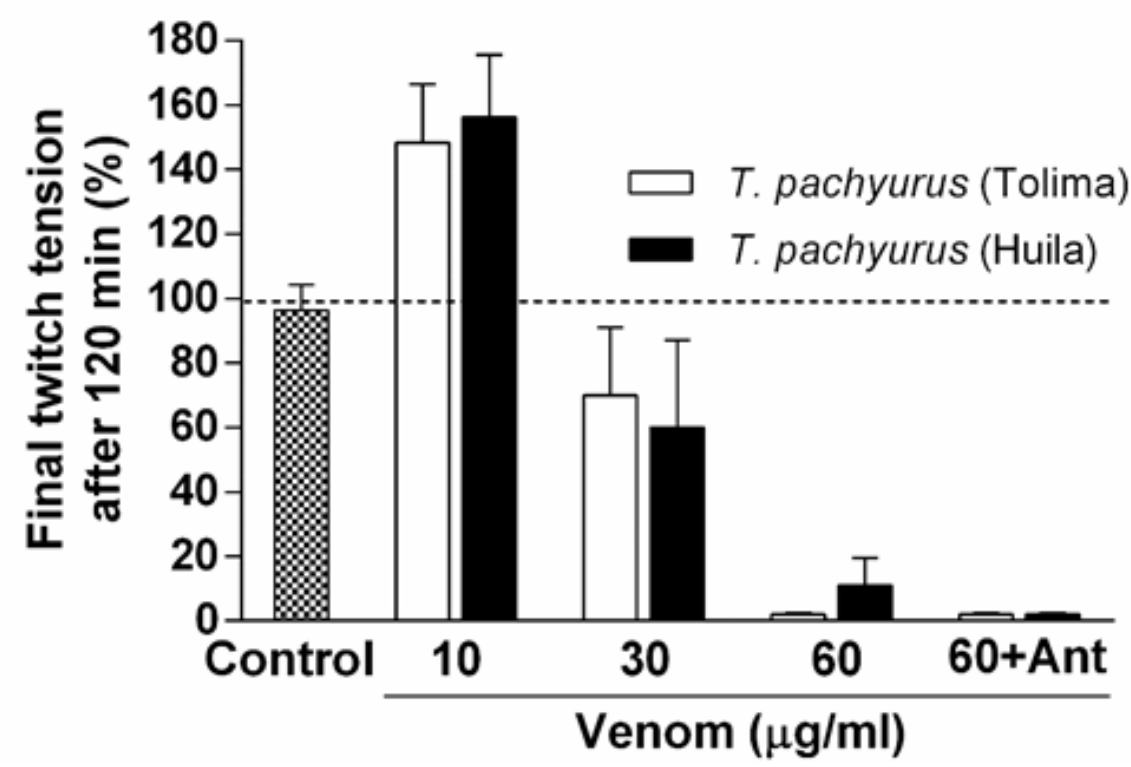

Figure 7. (A) Comparative neuromuscular activity between T. pachyurus venom from Tolima and Huila regions. (B) Comparative final twitch tension responses after 120 min incubation with venom from both regions and neutralization with scorpionic antivenom from Brazil. Note that there is not any significant difference in the neuromuscular activity caused by the venom from both regions as well as with the neutralization with antivenom. The points in $\mathbf{A}$ and columns in $\mathbf{B}$ are the mean $\pm \operatorname{SEM}(n=4)$. 


\section{Discussion}

Crude venom SDS-PAGE shows a high concentration of protein content with molecular mass between $34 \mathrm{kDa}$ and $97 \mathrm{kDa}$ and other ones with higher concentration between $14 \mathrm{kDa}$ and $7 \mathrm{kDa}$, these results coincide with bands reported by Barona et al. [23]. Tolima and Huila crude venoms showed variations in relative amounts of protein bands, these results are in concordance with those reported in other scorpions and arachnids where the components of the venom of a species may be more abundant in some individuals than in others due to individual variability in the composition of the venom $[10,20,46,47]$ where aspects such as geographic distribution, diet, climate, age, and sex have been an integral part of determining the venom components $[46,48,49]$. The chromatographic profiles of the venoms from the Huila and Tolima regions showed a difference in the peaks and their intensity. Essentially, well defined peaks eluting at $8.37 \mathrm{~min}, 25.43 \mathrm{~min}$, and $35.34 \mathrm{~min}$ presented in the venom from Tolima were visible with much less intensity in the venom from Huila (Fig. 3). The main peak in the Huila venom eluting at $43.40 \mathrm{~min}$ is missing in the Tolima venom. These findings could suggest a difference in the concentration of some of the components of the samples of these venoms from both regions.

The enzymatic profiles were similar to reported by Venancio et al. [50] and Almeida et al. [51], who also did not find phospholipase $\mathrm{A}_{2}$ enzymes in venoms from Tityus spp., $T$. serrulatus, T. bahiensis and T. stigmurus. On the other hand, proteolytic enzymes in scorpion venoms are associated with the activation of coagulation cascades, fibrinolytic activity, homeostatic imbalance or pre-digestion of preys [51] and these enzymes probably process and activate toxins and trypsinogen which contributing to the pancreatitis that is often observed in the victims of attacks by Tityus, by increasing the concentration of enzymes in the pancreatic secretion $[50,52]$.

Serine proteases, metalloproteases and hyaluronidases have been reported for the genus Tityus. In T. discrepans, serine and metalloproteases were found associated with fibrinolytic activity and anticoagulant effect. An anterease type metalloproteinase was reported for T. pachyurus named: TpachMP_A2 (UniProt V9ZAX6), which is capable of penetrating intact tissue and specifically cleaving soluble $\mathrm{N}$-ethylmaleimide-binding protein (SNARE) receptors involved in pancreatic secretion, thereby disrupting normal vesicular traffic $[53,54]$. The caseinolytic activity can be attributed to protease-type enzymes in the venom of T. pachyurus.

Despite the low level of inhibition, the results obtained through the bactericidal assays suggest that the crude venom has a direct effect against the bacterial growth or integrity of the gram-negative bacterium E. coli. and gram-positive $S$. aureus. Antimicrobial peptides derived from scorpion venom have gained great interest due to their potent activity, low rates of resistance and a unique mode of action, which have increased the interest of the pharmacological industry [8,9,55-58]. Duenas-Cuellar et al. [59] reported a toxin from Centruroides margaritatus venom that inhibiting the proliferation of the gram-negative bacteria Klebsiella pneumoniae. For the genus Tityus, these types of peptides for T. serrulatus, T. discrepans, T. costatus and T. obscurus are registered in the UniProt Consortium 2002-2018 database. [60-62]. For this reason, it is important not to rule out exploring other forms of antimicrobial activity such as fungal activity and it is suggested to carry out bactericidal activity tests with fractions of the T. pachyurus venom.

The insecticidal activity showed marketable differences between venom from Tolima and Huila. Only the venom extracted from Huila individuals showed insecticidal activity on B. dubia. Scorpions are animals that survive in extreme and adverse physical conditions, with nocturnal habits and remain hidden during the day, feeding on small insects [63]. According to literature, their venoms are considered a rich source of different compounds, however the best-known toxins are those specific for $\mathrm{Na}^{+}$or $\mathrm{K}^{+}$channels (NaScTxs and KTxs, respectively). These peptides act on ion channels with high affinity and specificity, and may also discriminate between ion channels of insects and mammals and can cause death or rapid paralyze of the prey by interacting with ion channels and/or receptors in the neuromuscular system as observed with the venom of Huila scorpions. Anti-insect toxins have been previously reported from Colombia scorpions: Rincon-Cortés et al. [64] reported antiinsect toxins in the venom of Tityus macrochirus from Colombia and Guerrero-Vargas et al. [32] reported the first anti-insect excitatory $\beta$ class NaScTx in the venom of T. pachyurus from Colombia, the differences between venom from Huila and Tolima regions should be deeply analyzed and could be associated with the variation in the chemical composition evidenced through the chromatographic analysis and SDS-PAGE carried out, however it is necessary to go deeper from a proteomic, transcriptomic and metabolomics approaches, and analyze the ecology in more details the ecology from both regions.

T. pachyurus venom from Huila and Tolima regions produced the same effect in PND preparations without any significant difference, both venoms produced $\sim 48-56 \%$ facilitation with the lowest concentration tested $(10 \mu \mathrm{g} / \mathrm{mL})$ and complete blockade with the highest concentration $(60 \mu \mathrm{g} / \mathrm{mL})$ after $\sim 40-90 \mathrm{~min}$. The neuromuscular action of T. pachyurus venom demonstrated in this present study comprises the first report with Colombian scorpion species. The action of Tityus venoms on the somatic neurotransmission has been poorly demonstrated in the last decades, with only a few studies reporting their neurotoxic mechanisms in vertebrate nerve-muscle preparations [65-71]. The neuromuscular facilitation produced by $T$. pachyurus venom at low concentrations and the rapid blockade of the twitch responses seen at high concentrations of this venom in PND preparations also were reported for the Brazilian species T. serrulatus [67] and T. bahiensis [70]. The neuromuscular action of scorpion venoms has been mostly associated with the presence of neurotoxins with high affinity for voltage-gated $\mathrm{Na}^{+}$ channels [70-71]. 


\section{Conclusions}

The results obtained in the biological and enzymatic activities suggest a difference between venoms from Huila and Tolima regions, which could be an indication of variation in the venom composition of T. pachyurus. Currently, there is no geographical barrier between the region of Tolima and Huila and, probably, intraspecific variation of T. pachyurus venom is a consequence of a combination of local environmental conditions and differences in the type of diet or/and predators. This study represents an advance towards the understanding of the variability in the venom of T. pachyurus.

\section{Acknowledgments}

The authors thank Rodrigo González Erik Camilo Gaitán, Angel Aparicio and Francisco Javier Rodriguez for the support in the fieldwork, Jolman Diaz Ortiz for the design and building of the electrostimulator, and Dr. Arie van der Meijden for his comments on the draft of this manuscript.

\section{Availability of data and materials}

The datasets generated during the current study are available from the corresponding author on reasonable request.

\section{Funding}

The present study was funded by Grupo de Investigación en productos Naturales de la Universidad del Tolima (GIPRONUT), Huiltur Corporation and Grupo de Investigación Biología y Ecología de Artrópodos (BEA). JCGG was supported by a scholarship from Entomopixel (www.entomopixel.com).

\section{Competing interests}

The authors declare that they have no competing interests.

\section{Authors' contributions}

JASG contributed with conceptualization, methodology, investigation, formal analysis, writing - original draft preparation, review and editing. JCGG contributed with the investigation, funding acquisition, supervision, formal analysis and review and editing. KATB, RSF and ATSFM contributed with investigation, formal analysis and writing-review and editing. WMA contributed with the conceptualization, funding acquisition, investigation, supervision, formal analysis and writing - review and editing. All authors read and approved the final manuscript.

\section{Ethics approval}

Animal experiments were approved by an institutional Committee for Ethics in Animal Use (CEUA/UNICAMP, protocol no. 50931/2018) and were done according to the general ethical guidelines for animal use established by the Brazilian Society of Laboratory Animal Science (SBCAL) and Brazilian legislation (Federal Law No. 11,794, of October 8, 2008), in conjunction with the guidelines for animal experiments established by the Brazilian National Council for Animal Experimentation (CONCEA) and EU Directive 2010/63/EU for the Protection of Animals Used for Scientific Purposes.

\section{Consent for publication}

Not applicable

\section{References}

1. de la Vega RCR, Schwartz EF, Possani LD. Mining on scorpion venom biodiversity. Toxicon. 2010 Dec 15;56(7):1155-61.

2. Schendel V, Rash LD, Jenner RA, Undheim EAB. The diversity of venom: the importance of behavior and venom system morphology in understanding its ecology and evolution. Toxins (Basel). 2019 Nov 14;11(11):666.

3. Herzig V. Arthropod assassins: crawling biochemists with diverse toxin pharmacopeias. Toxicon. 2019 Feb;158:33-7.

4. Gurevitz M, Karbat I, Cohen L, Ilan N, Kahn R, Turkov M, Stankiewicz M, Stühmer W, Dong K, Gordon D. The insecticidal potential of scorpion beta-toxins. Toxicon. 2007 Mar 15;49(4):473-89.

5. Hmed B, Serria HT, Mounir ZK. Scorpion peptides: potential use for new drug development. J Toxicol. 2013;2013:958797.

6. Zlotkin E, Miranda F, Lissitzky S. A factor toxic to crustacean in the venom of the scorpion Androctonus australis hector. Toxicon. 1972 May;10(3):211-6.

7. Carmo AO, Oliveira-Mendes BBR, Horta CCR, Magalhães BF, Dantas AE, Chaves LM, Chávez-Olórtegui C, Kalapothakis E. Molecular and functional characterization of metalloserrulases, new metalloproteases from the Tityus serrulatus venom gland. Toxicon. 2014 Nov;90:45-55.

8. Harrison PL, Abdel-Rahman MA, Miller K, Strong PN. Antimicrobial peptides from scorpion venoms. Toxicon. 2014 Sep;88:115-37.

9. Montaño-Pérez K, Vargas-Albores F. Péptidos antimicrobianos: un mecanismo de defensa ancestral con mucho futuro. Interciencia. 2002;27(1):21-7.

10. Abdel-Rahman MA, Omran MAA, Abdel-Nabi IM, Ueda H, McVean A. Intraspecific variation in the egyptian scorpion Scorpio maurus palmatus venom collected from different biotopes. Toxicon. 2009 Mar 1;53(3):349-59.

11. Chippaux JP, Goyffon M. Epidemiology of scorpionism: a global appraisal. Acta Trop. 2008 Aug;107(2):71-9.

12. González-Gómez JC, Valenzuela-Rojas JC, García LF, Pérez LMF, Guevara G, Buitrago S, Cubillos A, Van Der Meijden A. Sexual dimorphism in the biomechanical and toxicological performance in prey incapacitation of two morphologically distinct scorpion species (Chactas sp. and Centruroides sp.). Biol J Linn Soc. 2020 Jan;129(1):190-8.

13. Owen MD, Sloley BD. 5-hydroxytryptamine in the venom of the honey bee (Apis mellifera L.): variation with season and with insect age. Toxicon. 1988;26(6)577-81.

14. Mulfinger LM, Benton AW, Guralnick MW, Wilson RA. A qualitative and quantitative analysis of proteins found in vespid venoms. J Allergy Clin Immunol. 1986 May;77(5):681-6.

15. Hannan Jr CJ, Stafford CT, Rhoades RB, Wray BB, Baer H, Anderson $M C$. Seasonal variation in antigens of the imported fire ant Solenopsis invicta. J Allergy Clin Immunol. 1986 Aug;78(2):331-6.

16. Jakubowski JA, Kelley WP, Sweedler JV, Gilly WF, Schulz JR. Intraspecific variation of venom injected by fish-hunting Conus snails. J Exp Biol. 2005 Aug;208(15):2873-83.

17. Binford GJ. An analysis of geographic and intersexual chemical variation in venoms of the spider Tegenaria agrestis (Agelenidae). Toxicon. 2001 Jul;39(7):955-68.

18. Menezes MC, Furtado MF, Travaglia-Cardoso SR, Camargo ACM, Serrano SMT. Sex-based individual variation of snake venom proteome among eighteen Bothrops jararaca siblings. Toxicon. 2006 Mar;47(3):304-12.

19. Borges A, de Sousa L, Espinoza J, Melo MM, Santos RG, Kalapothakis E, Valadares D, Chávez-Olórtegui C. Characterization of Tityus scorpion venoms using synaptosome binding assays and reactivity towards venezuelan and brazilian antivenoms. Toxicon. 2008 Jan;51(1):66-79. 
20. Estrada-Gómez S, Cupitra NI, Arango WM, Muñoz LJV. Intraspecific variation of Centruroides Edwardsii venom from two regions of Colombia. Toxins (Basel). 2014 Jul 14;6(7):2082-96.

21. Ozkan $O$, Ciftci $G$. Individual variation in the protein profile of the venom of Mesobuthus gibbosus (Brullé, 1832, Scorpiones: Buthidae) from Turkey. J Venom Anim Toxins incl Trop Dis. 2010;16(3):505-8.

22. Casewell NR, Wüster W, Vonk FJ, Harrison RA, Fry BG. Complex cocktails: the evolutionary novelty of venoms. Trends Ecol Evol. 2013 Apr;28(4):219-29.

23. Barona J, Otero R, Núñez $\mathrm{V}$. Aspectos toxinológicos e inmunoquímicos del veneno del escorpión Tityus pachyurus Pocock de Colombia: capacidad neutralizante de antivenenos producidos en Latinoamérica. Biomed. 2004;24(1):42-9.

24. Guerrero-Vargas JA, Buitrago JRR, Ayerbe S, Daza EF, Vidal JTB Scorpionism and dangerous species of Colombia. Scorpion Venom. 2015;4:245-72.

25. Otero R, Navío E, Céspedes FA, Núñez MJ, Lozano L, Moscoso ER, Matallana C, Arsuza NB, García J, Fernández D, Rodas JH, Rodríguez OJ, Zuleta JE, Gómez JP, Saldarriaga M, Quintana JC, Núñez V, Cárdenas S, Barona J, Valderrama R, Paz N, Díaz A, Rodríguez OL, Martínez MD, Maturana R, Beltrán LE, Mesa MB, Paniagua J, Flórez E, Lourenço WR. Scorpion envenoming in two regions of Colombia: clinical, epidemiological and therapeutic aspects. Trans R Soc Trop Med Hyg. 2004 Dec;98(12):742-50.

26. Izquierdo LM, Rodríguez Buitrago JR. Cardiovascular dysfunction and pulmonary edema secondary to severe envenoming by Tityus pachyurus sting. Case report. Toxicon. 2012 Sep 15;60(4):603-6.

27. van der Meijden A, Coelho P, Rasko M. Variability in venom volume, flow rate and duration in defensive stings of five scorpion species. Toxicon. 2015 Jun 15;100:60-6.

28. Bradford MM. A rapid and sensitive method for the quantitation of microgram quantities of protein utilizing the principle of protein-dye binding. Anal Biochem. 1976 May 7;72(1-2):248-54.

29. Yábar Varas C. Manual de procedimientos de electroforesis para proteínas y ADN [Internet]. Lima, Peru: Serie de Normas Técnicas.. Instituto Nacional de Salud. 1 ed. 2003. p. 59.

30. Barona J, Batista CVF, Zamudio FZ, Gomez-Lagunas F, Wanke E, Otero $\mathrm{R}$, Possani LD. Proteomic analysis of the venom and characterization of toxins specific for $\mathrm{Na}^{+}$- and $\mathrm{K}^{+}$-channels from the Colombian scorpion Tityus pachyurus. Biochim Biophys Acta. 2006 Jan;1764(1):76-84.

31. Oliveira FN, Mortari MR, Carneiro FP, Guerrero-Vargas JA, Santos DM, Pimenta AMC, Schwartz EF. Another record of significant regional variation in toxicity of Tityus serrulatus venom in Brazil: a step towards understanding the possible role of sodium channel modulators. Toxicon. 2013 Oct;73:33-46.

32. Guerrero-Vargas JA, Mourão CBF, Quintero-Hernández V, Possani LD, Schwartz EF. Identification and phylogenetic analysis of Tityus pachyurus and Tityus obscurus novel putative $\mathrm{Na}^{+}$-channel scorpion toxins. PLoS One. 2012;7(2):e30478.

33. Six DA, Dennis EA. The expanding superfamily of phospholipase $A_{2}$ enzymes: classification and characterization. Biochim Biophys Acta. 2000 Oct 31;1488(1-2):1-19.

34. Gutiérrez JM, Chaves F, Rojas E, Elizondo J, Avila C, Cerdas L. Production of monovalent anti-Bothrops asper antivenom: development of immune response in horses and neutralizing ability. Rev Biol Trop. 1988 Nov;36(2B):511-7.

35. Kunitz M. Crystalline soybean trypsin inhibitor: II. General properties. J Gen Physiol. 1947 Mar 20;30(4):291-310.

36. Soto JG, Perez JC, Minton SA. Proteolytic, hemorrhagic and hemolytic activities of snake venoms. Toxicon. 1988;26(9):875-82.

37. Lomonte B, Gutierrez JM. La actividad proteolitica de los venenos de serpientes de Costa Rica sobre la caseína. Biol Trop. 1983;31(1):37-40.

38. Santa'Ana CD, Ticli FK, Oliveira LL, Giglio JR, Rechia CGV, Fuly AL, Selistre de Araújo HS, Franco JJ, Stabeli RG, Soares AM, Sampaio SV. BjussuSP-I: a new thrombin-like enzyme isolated from Bothrops jararacussu snake venom. Comp Biochem Physiol A Mol Integr Physiol. 2008 Nov;151(3):443-54.
39. Patel JB, Cockerill FR, Bradford PA, Eliopoulos GM, Hindler JA, Jenkins SG, Lewis JS, Limbago B, Miller LA, Nicolau DP, Powell M, Swenson JM, Traczewski MM, Turnidge JD, Weinstein MP, Zimmer BL. Methods for dilution antimicrobial susceptibility tests for bacteria that grow aerobically; Aprroved Standard-Tenth Edition. 10th ed. vol 35. n 2. Wayne: Clinical and Laboratory Standards Institute; 2015.

40. Pritchard SR, Phillips M, Kailasapathy K. Identification of bioactive peptides in commercial Cheddar cheese. Food Res Int. 2010 Jun;43(5):1545-8.

41. Escobar LM, Rivera A, Aristizábal FAG. Estudio comparativo de los métodos de resazurina y MTT en estudios de citotoxicidad en líneas celulares tumorales humanas. Vitae. 2010 Jan-Apr;17(1):67-74.

42. World Health Organization. Guidelines for laboratory and field testing of long-lasting insecticidal mosquito nets. 2005;1-18. Available from: https://apps.who.int/iris/bitstream/handle/10665/69007/WHO_CDS_ WHOPES_GCDPP_2005.11.pdf.

43. Yu H, Liu X, Dong X, Li C, Xing R, Liu S, Li P. Insecticidal activity of proteinous venom from tentacle of jellyfish Rhopilema esculentum Kishinouye. Bioorg Med Chem Lett. 2005 Nov 15;15(22):4949-52.

44. Quistad GB, Dennis PA, Skinner WS. Insecticidal activity of spider (Araneae), centipede (Chilopoda), Scorpion (Scorpionida), and Snake (Serpentes) Venoms. J Econ Entomol. 1992 Feb 1;85(1):33-9.

45. Floriano RS, Schezaro-Ramos R, Silva Jr NJ, Bucaretchi F, Rowan EG, Hyslop S. Neurotoxicity of Micrurus lemniscatus lemniscatus (South American coralsnake) venom in vertebrate neuromuscular preparations in vitro and neutralization by antivenom. Arch Toxicol. 2019 Jul;93(7):2065-86.

46. Oliveira FN, Mortari MR, Carneiro FP, Guerrero-Vargas JA, Santos DM, Pimenta AMC, Schwartz EF. Another record of significant regional variation in toxicity of Tityus serrulatus venom in Brazil: a step towards understanding the possible role of sodium channel modulators. Toxicon. 2013 Oct;73:33-46.

47. Omran MAA, McVean A. Intraspecific variation in scorpion Leiurus quinquestriatus venom collected from Egypt (Sinai and Aswan Deserts). J Toxicol Toxin Rev. 2000 Nov 23 ;19(3-4):247-64.

48. Pucca MB, Amorim FG, Cerni FA, Bordon KCF, Cardoso IA, Anjolette FAP, Arantes EC. Influence of post-starvation extraction time and prey-specific diet in Tityus serrulatus scorpion venom composition and hyaluronidase activity. Toxicon. 2014 Nov;90:326-36.

49. Borges A, Rojas de Arias A, de Almeida Lima S, Lomonte B, Díaz C, Chávez-Olórtegui C, Graham MR, Kalapothakis E, Coronel C, de Roodt AR. Genetic and toxinological divergence among populations of Tityus trivittatus Kraepelin, 1898 (Scorpiones: Buthidae) inhabiting Paraguay and Argentina. PLoS Negl Trop Dis. 2020 Dec 14;14(12):e0008899.

50. Venancio EJ, Portaro FCV, Kuniyoshi AK, Carvalho DC, Pidde-Queiroz G, Tambourgi DV. Enzymatic properties of venoms from brazilian scorpions of Tityus genus and the neutralisation potential of therapeutical antivenoms. Toxicon. 2013 Jul;69:180-90.

51. Almeida FM, Pimenta AMC, de Figueiredo SG, Santoro MM, MartinEauclaire MF, Diniz CR, de Lima ME. Enzymes with gelatinolytic activity can be found in Tityus bahiensis and Tityus serrulatus venoms. Toxicon. 2002 Jul;40(7):1041-5.

52. Fletcher PJ, Fletcher M, Weninger K, Anderson T, Martin B. Vesicleassociated membrane protein (VAMP) cleavage by a new metalloprotease from the Brazilian scorpion Tityus serrulatus. J Biol Chem. 2010 Mar 5;285(10):7405-16.

53. Ortiz E, Rendón-Anaya M, Rego SC, Schwartz EF, Possani LD. Antareaselike $\mathrm{Zn}$-metalloproteases are ubiquitous in the venom of different scorpion genera. Biochim Biophys Acta. 2014 Jun;1840(6):1738-46.

54. Zornetta I, Scorzeto M, Dos Reis PVM, De Lima ME, Montecucco C, Megighian A, Rossetto $O$. Electrophysiological characterization of the antarease metalloprotease from Tityus serrulatus venom. Toxins (Basel). 2017 Feb 27;9(3):81.

55. Carmo AO, Oliveira-Mendes BBR, Horta CCR, Magalhães BF, Dantas $A E$, Chaves LM, Kalapothakis E. Molecular and functional characterization of metalloserrulases, new metalloproteases from the Tityus serrulatus venom gland. Toxicon. $2014 \mathrm{Nov} ; 90: 45-55$. 
56. Rádis-Baptista G, Konno K. Arthropod venom components and their potential usage. Toxins (Basel). 2020 Jan 25;12(2):82.

57. Seyfi R, Kahaki FA, Ebrahimi T, Montazersaheb S, Eyvazi S, Babaeipour V, Tarhriz V. Antimicrobial peptides (AMPs): roles, functions and mechanism of action. Int J Pept Res Ther. Springer; 2020;26(3):1451-63.

58. Park J, Oh JH, Kang HK, Choi MC, Seo CH, Park Y. Scorpion-venomderived antimicrobial peptide Css54 exerts potent antimicrobial activity by disrupting bacterial membrane of zoonotic bacteria. Antibiotics. 2020 Nov 20;9(11):831.

59. Dueñas-Cuellar RA, Kushmerick C, Naves LA, Batista IFC, GuerreroVargas JA, Pires Jr OR, Fontes W, Castro MS. Cm38: a new antimicrobial peptide active against Klebsiella pneumoniae is homologous to $\mathrm{Cn} 11$. Protein Pept Lett. 2015;22(2):164-72.

60. Guo X, Ma C, Du Q, Wei R, Wang L, Zhou M, Chen T, Shaw C. Two peptides, TsAP-1 and TsAP-2, from the venom of the brazilian yellow scorpion, Tityus serrulatus: evaluation of their antimicrobial and anticancer activities. Biochimie. 2013 Sep;95(9):1784-94.

61. Almeida F, Pimenta AMC, De Figueiredo SG, Santoro MM, MartinEauclaire MF, Diniz CR, De Lima ME. Enzymes with gelatinolytic activity can be found in Tityus bahiensis and Tityus serrulatus venoms. Toxicon. 2002 Jul;40(7):1041-5.

62. Ruiming Z, Yibao M, Yawen H, Zhiyong D, Yingliang W, Zhijian C, Wenxin, L. Comparative venom gland transcriptome analysis of the scorpion Lychas mucronatus reveals intraspecific toxic gene diversity and new venomous components. BMC Genomics. 2010 Jul 28;11:452.

63. Schwartz EF, Mourão CBF, Moreira KG, Camargos TS, Mortari MR. Arthropod venoms: a vast arsenal of insecticidal neuropeptides. Biopolymers. 2012:98(4):385-405.
64. Rincón-Cortés CA, Olamendi-Portugal T, Carcamo-Noriega EN, Santillán EG, Zuñiga FZ, Reyes-Montaño EA, Vega Castro NA, Possani LD. Structural and functional characterization of toxic peptides purified from the venom of the colombian scorpion Tityus macrochirus. Toxicon. 2019 Nov; 169:5-11.

65. Warnick JE, Albuquerque EX, Diniz CR. Electrophysiological observations on the action of the purified scorpion venom, tityustoxin, on nerve and skeletal muscle of the rat. J Pharmacol Exp Ther. 1976 Jul;198(1):155-67.

66. Basu A, Gomes A, Gomes A, Dasgupta SC, Lahiri SC. Pharmacology of scorpion (Lychas laevifrons Pock) venom with special reference to its neuromuscular activity. Indian J Exp Biol. 1989 Dec;27(12):1028-31.

67. Basu A, Gomes A, Gomes A, Dasgupta SC, Lahiri SC. Histamine, 5-HT and hyaluronidase in the venom of the scorpion Lychas laevifrons (Pock.). Indian J Med. 1990 Oct;92:371-3.

68. Borja-Oliveira CR, Pertinhez TA, Rodrigues-Simioni L, Spisni A. Positive inotropic effects of Tityus cambridgei and T. serrulatus scorpion venoms on skeletal muscle. Comp Biochem Physiol C Toxicol Pharmacol. 2009 Apr;149(3):404-8.

69. Vatanpour H, Jalali A, Rowan EG, Rahim F. Effects of odontobuthus doriae scorpion venom on mouse sciatic nerve. Iran J Pharm Res. 2013;12(Suppl):145-51.

70. Dos Santos DS, Carvalho EL, de Lima JC, Breda RV, Oliveira RS, de Freitas TC, Salamoni SD, Domingues MF, Piovesan AR, Boldo JT, de Assis DR, da Costa JC, Dal Belo CA, Pinto PM. Bothriurus bonariensis scorpion venom activates voltage-dependent sodium channels in insect and mammalian nervous systems. Chem Biol Interact. 2016 Oct 25;258:1-9.

71. De Cássia Collaço R, Hyslop S, Rocha T, Dorce VAC, Rowan EG, Antunes E. Neurotoxicity of Tityus bahiensis (brown scorpion) venom in sympathetic vas deferens preparations and neuronal cells. Arch Toxicol. 2020 Sep;94:3315-27. 